\title{
Efficient expression of heterologous genes by the introduction of the endogenous glyceraldehyde-3-phosphate dehydrogenase gene intron 1 in Ganoderma lucidum
}

\author{
Hao You' ${ }^{1}$ Bin Sun ${ }^{1}, \mathrm{Na} \mathrm{Li}^{2}$ and Jun-Wei Xü ${ }^{1 *}$
}

\begin{abstract}
Background: Ganoderma lucidum, a well-known medicinal mushroom, has received wide attention as a promising cell factory for producing bioactive compounds. However, efficient expression of heterologous genes remains a major challenge in Ganoderma, hindering metabolic regulation research and molecular breeding of this species.

Results: We show that the presence of glyceraldehyde-3-phosphate dehydrogenase gene (gpd) intron 1 at the $5^{\prime}$ end of, the $3^{\prime}$ end of, or within the heterologous phosphinothricin-resistant gene (bar) is efficient for its expression in G. lucidum. The enhanced expression of bar is exhibited by the higher accumulation of mRNA and increased amounts of protein. Moreover, the insertion of the gpd intron 1 in the $\beta$-glucuronidase gene (gus) elevates its mRNA accumulation and enzyme activity, which facilitates the use of this reporter gene in Ganoderma.

Conclusions: This study has demonstrated the importance of the introduction of gpd intron 1 for the efficient expression of bar and gus in G. lucidum. The presence of the gpd intron 1 in heterologous genes increases levels of mRNA accumulation and protein expression in basidiomycete Ganoderma. The developed method may be utilized in upregulating the expression of other heterologous genes in Ganoderma.
\end{abstract}

Keywords: Ganoderma, Expression of heterologous genes, Intron, mRNA accumulation, Protein expression, Enzyme activity

\section{Background}

Ganoderma lucidum, a well-known medicinal mushroom, can synthesize a variety of bioactive products such as ganoderic acids, ganoderols, polysaccharides, immunomodulatory proteins, nucleotides, and sterols [1]. It has received wide attention as a promising cell factory for producing these valuable compounds in recent years [27]. The genome, transcriptome, and proteome of G. lucidum have been sequenced [8-10]. G. lucidum has been

\footnotetext{
*Correspondence: xjuwei@163.com; jwxu@kust.edu.cn

${ }^{1}$ Faculty of Life Science and Technology, Kunming University of Science and Technology, Kunming 650500, China

Full list of author information is available at the end of the article
}

suggested as a model species for studying the biology of basidiomycetes and biosynthesis of secondary metabolites $[8,11]$.

Molecular genetic approaches tools such as genetic transformation, disruption, and deletion of target genes have been developed in G. lucidum [12-16]. However, efficient expression of heterologous genes remains a main challenge in Ganoderma, although it would be valuable for metabolic regulation and molecular breeding. Successful expression of heterologous genes in basidiomycetes may depend on several factors, including an effective promoter, codon optimization, and the presence of introns [12, 17, 18]. Among those elements, introns have a significant effect on the expression of heterologous 
genes. In some mushroom species such as Clitopilus passeckerianus, Coprinus cinereus, and Schizophyllum commune, the addition of an intron is required for the efficient expression of the green fluorescent protein gene $(g f p)$, the hygromycin-resistant gene, and the phleomycin-resistant gene [19-21].

Intron-containing G. lucidum genes represent $85.4 \%$ of predicted genes (approximately 16,113) in its 43.3$\mathrm{Mb}$ genome [8], indicating the importance of introns in Ganoderma. In a previous study, we found that an extra fragment, including gpd exon 1, intron 1, and 3-bp exon 2 at the $5^{\prime}$ end of $g f p$ and phosphinothricin-resistant gene (bar), was essential for their expression in G. lucudium [16]. However, the role of $g p d$ intron 1 in regulating the expression of heterologous genes has not been yet thoroughly investigated in G. lucidum. Furthermore, how gpd intron 1 affects gene transcription, protein expression, and enzyme activity when heterologous genes are expressed in G. lucidum remains unclear.

In this study, we show that the presence of $g p d$ intron 1 at different locations is effective in enhancing the expression of heterologous bar in G. lucidum. The efficient expression of heterologous genes is due to higher accumulation of mRNA and increased amount of protein. Moreover, the insertion of gpd intron 1 in the gus enhances its mRNA and enzyme activity, which facilitates the use of this reporter gene in Ganoderma.

\section{Results and discussion}

Endogenous gpd intron 1 increases the expression of the heterologous bar in G. Iucidum

Our previous study has shown that the insertion of the gpd fragment containing the first exon (6 bp), the first intron $(67 \mathrm{bp})$, and part of the second exon (3 bp) at the $5^{\prime}$ end of the bar and $g f p$ exerts a significant influence on protein expression. To investigate the effect of the endogenous gpd intron 1 on protein expression in G. lucidum, we constructed plasmids in which the heterologous codon-optimized phosphinothricin-resistance gene (opbar)-flag was regulated by the endogenous $g p d$ promoter and the succinate dehydrogenase gene $(s d h)$ terminator of G. lucidum (pJW-EXP-opbar-flag) (Fig. 1). Alternatively, the opbar-flag was cloned in similar plasmids that contained the gpd intron 1 directly upstream of the start codon (pJW-EXP-in-opbar-flag), 6 bp downstream of the translation start site of bar (pJW-EXP-in (M)-opbar-flag), and directly downstream of the stop codon (pJW-EXP-opbar-flag-in) (Fig. 1). These plasmids also contained a carboxin-resistance cassette, allowing selection of transformants on CYM plates with carboxin. After G. lucidum protoplasts were transformed with intron-containing and intronless opbar-flag plasmids (pJW-EXP-opbar-flag), we obtained carboxin-resistant colonies with all used plasmids. However, when these carboxin-resistance transformants were re-screened
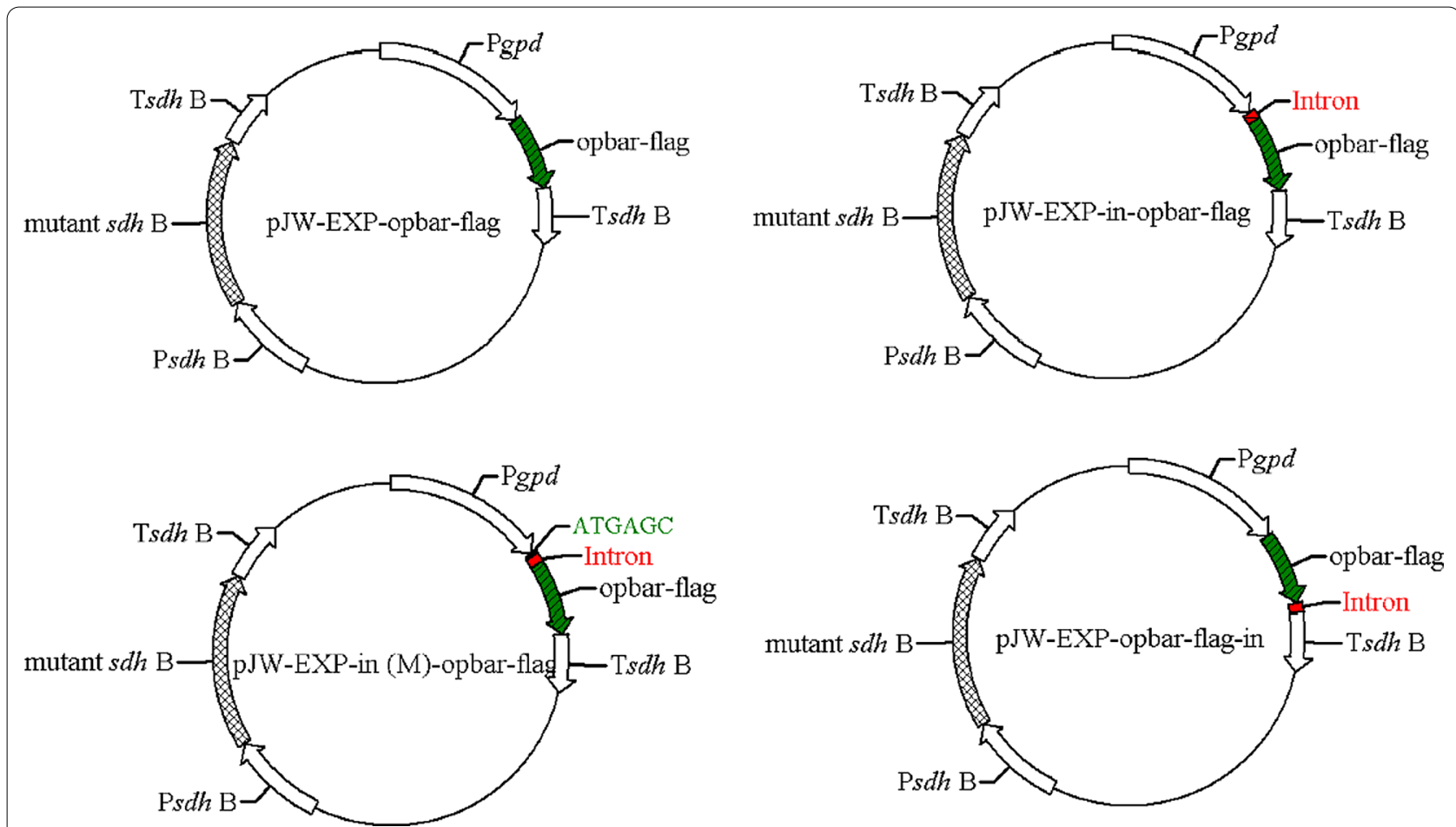

Fig. 1 Structure of opbar-flag plasmids used for G. lucidum transformation. See "Methods" for details on plasmid construction 
on CYM plates including phosphinothrin, no phosphinothrin-resistant colonies were obtained with plasmid pJW-EXP-opbar-flag. The phosphinotrhrin-resistance transformants were obtained with intron-containing plasmids pJW-EXP-in-opbar-flag, pJW-EXP-in (M)opbar-flag, and pJW-EXP-opbar-flag-in (Fig. 2A, Additional file 1: Figs. S1A and S2A). PCR analysis showed that the opbar-flag has integrated into the genomes of transformants pJW-EXP-opbar-flag, transformants pJWEXP-in-opbar-flag, pJW-EXP-opbar-in (M)-flag, and pJW-EXP-opbar-flag-in (Fig. 2B, Additional file 1: Figs. S1B and S2B). These results indicated that the introduction of the endogenous gpd intron 1 is important for efficient expression of heterologous bar in G. lucidum. Moreover, this effect was independent of the position of the gpd intron 1. Positive effects of intron on transgene expression have also been observed in other basidiomycetes such as Agaricus bisporus, C. cinereus, Phanerochaete chrysosporium, S. commune, C. passeckerianus and Trichoderma viride [20-24]. Enhancement of gene expression by introns may play a role in those organisms that generally possess introns in their genes [22].

\section{Enhancement is associated with increased levels of mRNA}

The transformant pJW-EXP-in-opbar-flag was chosen with the tranformant pJW-EXP-opbar-flag to study how the gpd intron 1 affects gene transcription and protein expression. The presence of opbar-flag in the genome of transformants pJW-EXP-opbar-flag and pJW-EXPin-opbar-flag was further determined by molecular hybridization. The genome of transformants pJW-EXPopbar-flag and pJW-EXP-in-opbar-flag were digested with NheI and probed with an opbar fragment (Fig. 3A, B). Southern blot analysis verified that these transformants had insertions of opbar, with single or multiple copies in their genomes. Single-copy integration of opbar-flag event was detected in the genomes of transformants pJW-EXP-opbar-flag T1, T4, and T5, and pJW-EXP-in-opbar-flag T1, T3, and T5. To minimize copy-number effect, the transcription level of opbar was analyzed in transformants PJW-EXP-opbar-flag T1 and T5, and pJW-EXP-in-opbar-flag T1 and T3 carrying a single-copy opbar by real-time qRT-PCR analysis. The results showed high transcription levels in transformants pJW-EXP-in-opbar-flag T1 and T3 bearing gpd intron 1 in opbar and low levels for transformants pJW-EXP-opbar-flag T1, and T5 containing opbar without gpd intron 1. No significant transcription difference was observed between pJW-EXP-in-opbar-flag T1 and T5. The transcription level of opbar in transformants pJW-EXP-in-opbar-flag T1 and T3 was, respectively, 12.3- and 10.1-fold higher than in transformant pJWEXP-in-opbar-flag T1 (Fig. 3C). Our results indicated that $g p d$ intron 1 increased the transcription level of heterologous opbar in G. lucidum. Previous studies have suggested that introns increased the level of mRNA possibly by enhancing maturation and stability of transcripts [25]. The difference in transcription level between $\mathrm{pJW}$ EXP-in-opbar-flag T1 and T3 might be relevant to integration position effects [26].

\section{The effect of the gpd intron 1 on protein yield of heterologous opbar}

Proteins isolated from transformants pJW-EXP-opbarflag T1, and T5, and pJW-EXP-in-opbar-flag T1 and T3 were analyzed by western blotting (Fig. 4). A protein of $\approx 22 \mathrm{kDa}$ was detectable in the transformants pJW-EXP-in-opbar-flag T1 and T3. However, it was not observed in transformants pJW-EXP-opbar-flag $\mathrm{T} 1$ and T5 containing opbar without the gpd intron
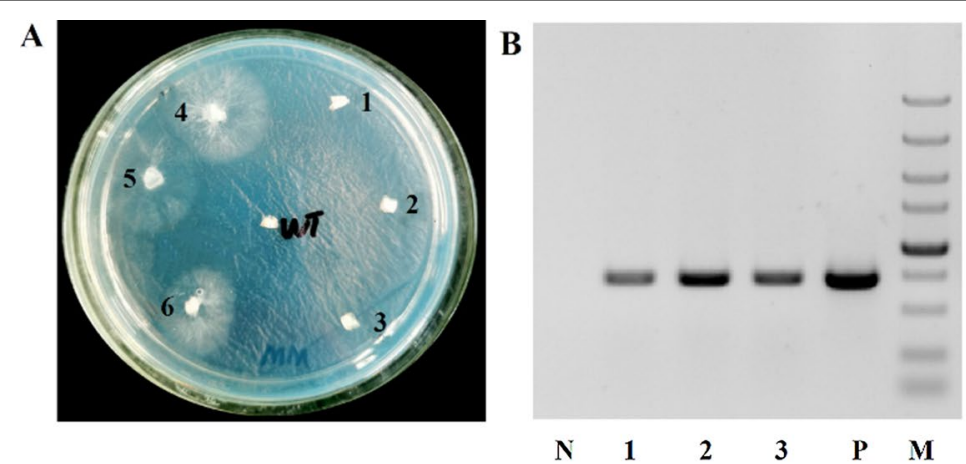

Fig. 2 Selection of phosphinothrin-resistant transformants on a selective CYM plate. A Transformants on a selective CYM plate. 1, 2, 3: the strain transformed with pJW-EXP-opbar-flag; 4, 5, 6: the strain transformed with pJW-EXP-in-opbar-flag. B Identificaton of G. lucidum transformants by PCR. Lane M, DNA marker DL5000; Lane P, pJW-EXP-in-opbar-flag as positive control; Lane N, negative control; Lane 1, 2, 3, the transformants pJW-EXP-opbar-flag; Lane 4, 5, 6, the transformant pJW-EXP-in-opbar-flag 

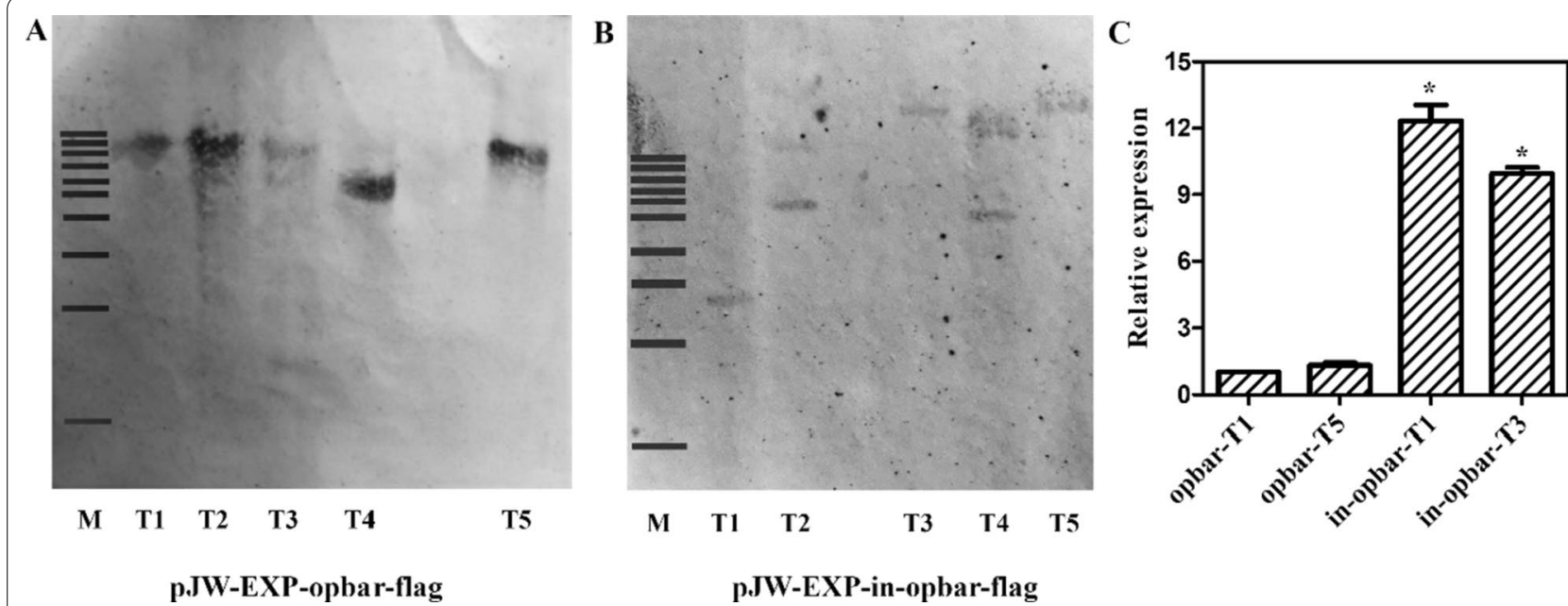

Fig. 3 Detection of copies of opbar and transcriptional levels of opbar in different G. lucidum transformants. A pJW-EXP-opbar-flag transformants. B pJW-EXP-in-opbar-flag transformants. C The relative expression levels of opbar in transformants opbar-T1, opbar-T5, in-opbar-T1, and in-opbar-T3. Lane M, DNA marker 1 kb ladder

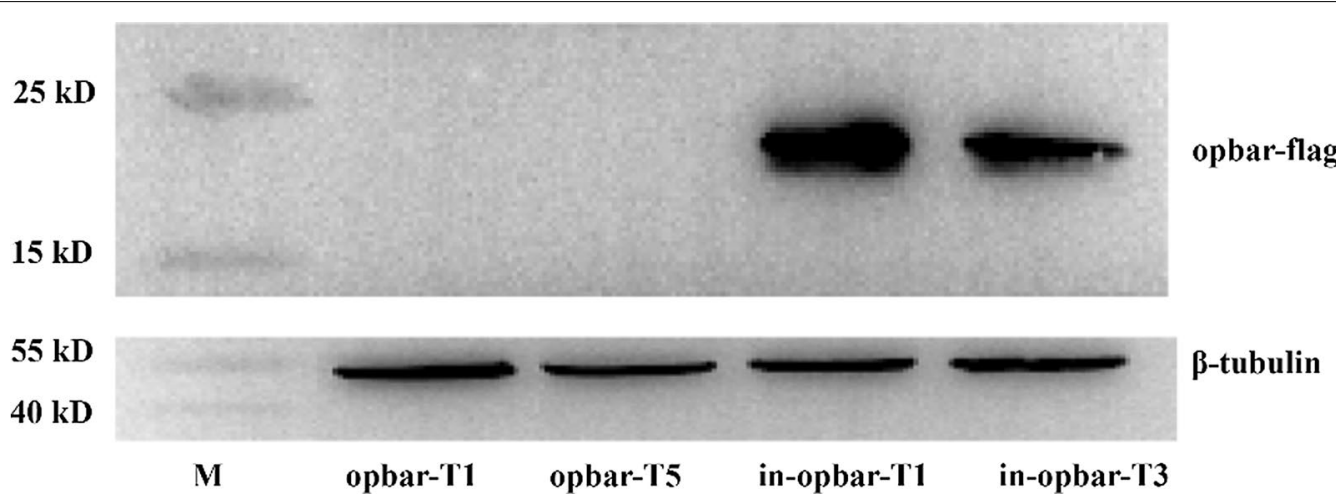

Fig. 4 Analysis of opbar-flag amount by SDS-PAGE in transformants opbar-T1, opbar-T5, in-opbar-T1, and in-opbar-T3. Lane M, protein marker

1. The band at $22 \mathrm{kDa}$ that was recognized by flagspecific antibodies was the opbar-flag protein, as the molecular weight was similar to the predicted value. As shown in Fig. 4, the amount of opbar-flag protein also increased with the introduction of gpd intron 1. These results coincided with those of qRT-PCR analysis and phosphinothrin-resistance screening. Gpd intron 1 enhanced protein expression both at the RNA and protein levels. Opbar protein levels did not correlate with opbar mRNA levels in the intronless G. lucidum transformants, indicating that gpd intron 1 may also enhance the efficiency of translation besides increasing mRNA content by affecting transcription and stability of mRNA [27, 28]. The detailed mechanism of enhancement of introns on the translation of heterologous genes requires further investigation.

\section{Introduction of $g p d$ intron 1 enhances $\beta$-glucuronidase (GUS) expression}

To confirm the positive effect of gpd intron 1 on the expression of heterologous genes, we also constructed plasmids pJW-EXP-opgus and pJW-EXP-in-opgus (Fig. 5A) and transformed these into Ganoderma protoplasts. These plasmids contain a carboxin-resistant cassette for transformation selection and the full codon-optimized gus (opgus) cassette (pJW-EXPopgus) or the intron-opgus cassette. Carboxin-resistant colonies were screened for transgenes by genome PCR (Additional file 1: Fig. S3) and subsequently were further analyzed by Southern blotting. The results showed that opgus and intro-opgus had integrated into the genome of the recipient as single copies in transformants pJW-EXP-opgus T1, T2, T3, and T4, and transformants pJW-EXP-in-opgus T1 (Fig. 5B). Real-time 
A
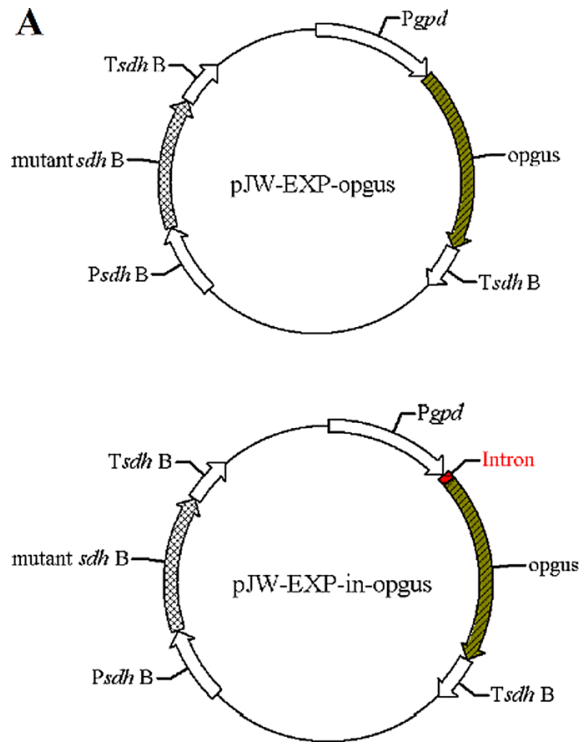

B

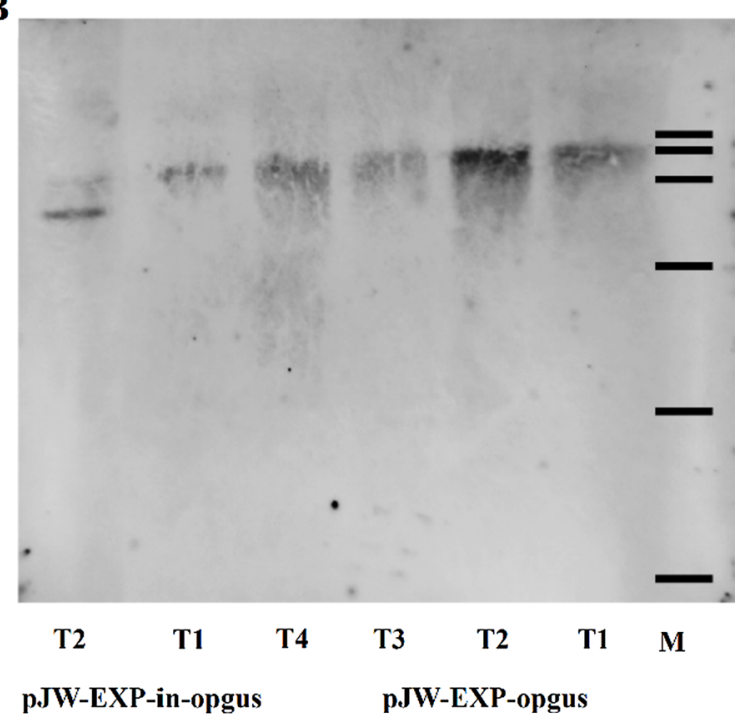

Fig. 5 Detection of copies of opgus in different G. lucidum transformants. A Structure of opgus plasmids. B Genome southern blot analysis of pJW-EXP-opgus transformant T1,T2, T3, and T4, and pJW-EXP-in-opgus transformants T1 and T2. Lane M, DNA marker DL 15,000

qRT-PCR analysis showed that the transcription level of opgus in transformant pJW-EXP-in-opgus T1 was 3.8-fold higher than that in transformants PJW-EXPopgus T1 and T2 without gpd intron 1 (Fig. 6A). The increase in transcription level relative to the intronless control ranged from 3.8-fold for opgus to 12.3-fold for opbar, which may be dependent on the cDNA sequence and the transcription level of the intronless heterologous gene [27, 29]. Histochemical staining analysis was also performed to detect expression of opgus in wild-type (WT), and transformants pJW-EXP-opgus $\mathrm{T} 2$ and PJW-EXP-in-opgus T1. Figure $6 \mathrm{~B}$ shows that GUS activity was observed in the mycelia of transformants pJW-EXP-opgus T2 and pJW-EXP-in-opgus T1, while no blue staining was detected in the WT mycelia. Moreover, GUS activity in transformant pJW-EXP-inopgus T1 was higher than that in transformant $\mathrm{pJW}$ EXP-opgus T2. Again, our results showed that gpd intron 1 enhanced the opgus transcription and GUS enzyme activity in G. lucidum. It may thus be possible
A

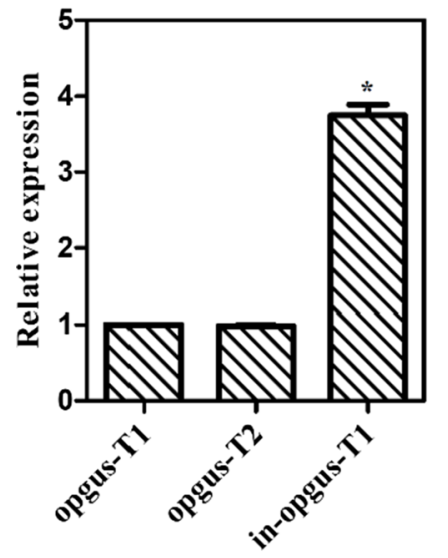

B

WT

opgus-T2

in-opgus-T 1

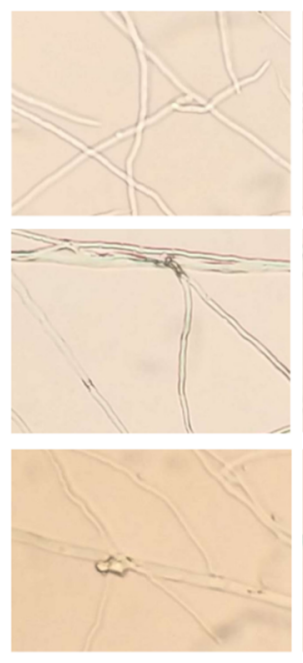

0 min

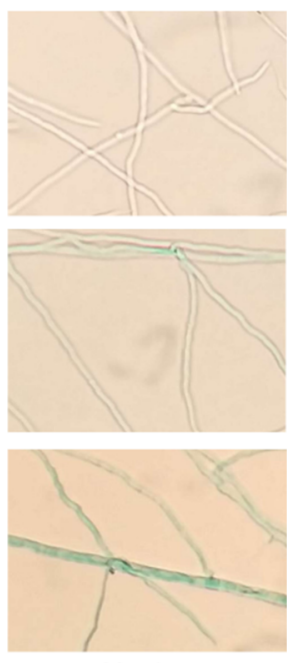

$20 \mathrm{~min}$

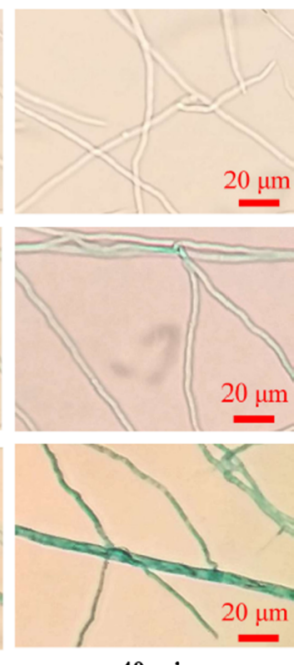

$40 \mathrm{~min}$

Fig. 6 The relative expression levels of $\operatorname{opbar}(\mathbf{A})$ in and histochemical staining $(\mathbf{B})$ of transformants opgus-T1, opgus-T2, and in-opgus-T1 
to efficiently express other heterologous genes in Ganoderma by introducing the gpd intron 1 .

\section{Conclusions}

This work demonstrated the importance of introducing gpd intron 1 for the efficient expression of opbar and gus in G. lucidum. The presence of gpd intron 1 in heterologous genes enhances mRNA accumulation and protein expression in basidiomycete Ganoderma. The developed method can be applicable to upregulate the expression of other heterologous genes in Ganoderma.

\section{Methods}

\section{Strains and media}

Monokaryotic G. lucidum 5.616-1 strain [30] was cultured in CYM plates $(10 \mathrm{~g} / \mathrm{L}$ maltose, $20 \mathrm{~g} / \mathrm{L}$ glucose, $2 \mathrm{~g} / \mathrm{L}$ tryptone, $2 \mathrm{~g} / \mathrm{L}$ yeast extract, $0.5 \mathrm{~g} / \mathrm{L} \mathrm{MgSO}_{4}$, $4.6 \mathrm{~g} / \mathrm{L} \mathrm{KH}_{2} \mathrm{PO}_{4}$ and $10 \mathrm{~g} / \mathrm{L}$ agar) and in transformations. Escherichia coli strain DH5 $\alpha$ was used in the construction and transformation of plasmids. The mycelia of $G$. lucidum were cultured in fermentation medium $(35 \mathrm{~g} / \mathrm{L}$ glucose, $1 \mathrm{~g} / \mathrm{L} \mathrm{KH}_{2} \mathrm{PO}_{4} \cdot \mathrm{H}_{2} \mathrm{O}, 0.5 \mathrm{~g} / \mathrm{L} \mathrm{MgSO}_{4} \cdot 7 \mathrm{H}_{2} \mathrm{O}, 5 \mathrm{~g} / \mathrm{L}$ peptone, $2.5 \mathrm{~g} / \mathrm{L}$ yeast extract, and $0.05 \mathrm{~g} / \mathrm{L}$ vitamin $\mathrm{B} 1$, $\mathrm{pH} 5.5)$ in the dark at $30^{\circ} \mathrm{C}[31,32]$.

\section{Plasmid construction}

The codon optimized phosphinothricin-resistance gene (opbar)-flag, gpd gene intron 1 (in)-opbar-flag, in(M)-opbar-flag, opbar-flag-in, opgus, and in-opgus (Additional file 1) were synthesized by Sangon Co., Ltd. (Shanghai, China). These genes were ligated into pUC57 (Sangon) to produce plasmids, pUC57-opbar-flag, pUC57-in-opbar-flag, pUC57-in (M)-opbar-flag, pUC57opbar-flag-in, pUC57-opgus, and pUC57-in-opgus, respectively.

The opbar-flag, in-opbar-flag, in(M)-opbar-flag, and opbar-flag-in genes were PCR amplified from plasmids pUC57-opbar-flag, pUC57-in-opbar-flag, pUC57-in (M)-opbar-flag, and pUC57-opbar-flag-in using primers opbar-flag-F/opbar-flag-R, in-opbar-flag F/opbar-flag-R, opbar-flag F2/opbar-flag-R, and opbar-flag-F/opbar-flag R2 (Additional file 1: Table S1), respectively. These PCR products were fused into plasmid pJW-EXP [13] that were digested with NheI and SmaI using the ClonExpress MultiS One Step Cloning Kit (Vazyme, Nanjing), yielding plasmid pJW-EXP-opbar-flag, pJW-EXP-in-opbar-flag, pJW-EXP-in(M)-opbar-flag, and pJW-EXP-opbar-flag-in, respectively.

The opgus and in-opgus genes were PCR amplified from plasmids pUC57-opgus and pUC57-in-opgus using primers opgus F/opgus $\mathrm{R}$ and in-opgus F/opgus $\mathrm{R}$ (Additional file 1: Table S1), respectively. The obtained products were fused into plasmid pJW-EXP that was digested with NheI and SmaI using the ClonExpress MultiS One Step Cloning Kit (Vazyme, Nanjing) to generate plasmids pJW-EXP-opgus and pJW-EXP-in-opgus, respectively.

\section{Genetic transformation of G. lucidum and selection of transformants}

Transformation of G. lucidum protoplasts was performed according to our previous studies [13,33]. The suspensions of G. lucidum protoplasts and plsmids in PTC buffer ( $50 \mathrm{mM} \mathrm{CaCl}_{2}, 10 \mathrm{mM}$ Tris- $\mathrm{HCl}$ buffer ( $\left.\mathrm{pH} 7.5\right)$, and $60 \% \mathrm{w} / \mathrm{v}$ PEG 4000) were plated onto CYM selective plates containing $0.6 \mathrm{M}$ mannitol and $2 \mu \mathrm{g} / \mathrm{L}$ carboxine. After 14 days of incubation at $30{ }^{\circ} \mathrm{C}$, carboxin-resistant transformants were screened for phosphinothricinresistance protein and GUS expression. The transformants expressing opbar were screened on CYM plates with $150 \mathrm{mg} / \mathrm{L}$ phosphinothricin. The genome of these transformants was extracted for PCR amplification of the fused fragment of gpd promoter and opbar using primers gpd-id-F/opbar-id-R. The transformants expressing opgus were identified by PCR amplification of the fused fragment of gpd promoter and opgus using primers gpd-id-F/opgus-R.

\section{Nucleic acid isolation}

Ganoderma lucidum mycelia were harvested, frozen, and powdered in liquid nitrogen. Genomic DNA was isolated employing the cetyltrimethylammonium bromide (CTAB) method. Total RNA was isolated using TRIzol reagent (Invitrogen, Carlsbad, CA, USA) according to the manufacturer's protocols and treated with RNase-free DNase I before use.

\section{Southern blots}

DNA samples from G. lucidum transformants were digested with NheI and separated on a $0.7 \%$ agarose gel. The opbar $(0.54 \mathrm{~kb})$ and opgus $(0.95 \mathrm{~kb})$ fragment amplified from plasmids pJW-EXP-opbar-flag and pJWEXP-opgus with primers bar probe $\mathrm{F} /$ bar probe $\mathrm{F}$ and gus probe F/gus probe $\mathrm{R}$ were used as probes. Southern blot analysis was conducted under conditions recommended for the digoxigenin (DIG) hybridization system by Mylab ${ }^{\mathrm{TM}}$ (Beijing, China).

\section{Quantitative real-time (qRT)-PCR analysis}

Approximately $1 \mathrm{mg}$ total RNA was used as template, and reverse transcription was performed using the PrimeScript $^{\mathrm{TM}} \mathrm{RT}$ reagent Kit (Takara, China) following the manufacturer's instructions. The transcription levels of opbar and opgus were determined by qRT-PCR as previously described $[6,16]$. The $18 \mathrm{~S}$-rRNA transcript was used as internal control to normalize relative transcription levels. For opbar and opgus, the transcription level in 
opbar-flag and opgus strains was set to 1.0, and the relative transcription levels in other strains were presented as fold changes relative to the reference level. The primers qRT-bar-F/qRT-bar-R, qRT-gus-F/qRT-gus-R, and qRT-18S-F/qRT-18S-R (Additional file 1: Table S1) were used for amplification of the opbar, opgus, and 18S rRNA genes, respectively.

\section{Western blot analysis}

Ganoderma lucidum mycelia were washed and homogenized in $1 \mathrm{~mL}$ of lysis buffer (25 mM Tris base (pH 7.4), $200 \mathrm{mM}$ glycine, $5 \mathrm{mM}$ EDTA, $1 \mathrm{mM}$ phenylmethyl sulfonyl fluoride, and $1 \mathrm{mM}$ 2-mercaptoethanol). The homogenates were centrifuged at $12,000 \times g$ for $20 \mathrm{~min}$ at $4{ }^{\circ} \mathrm{C}$, then protein concentration in the supernatants was determined using the Bradford method. For western bolt analysis, $30 \mu \mathrm{g}$ of protein was separated on a $12 \%$ SDS-polyacrylamide gel and electro-transferred to a polyvinylidene difluoride membrane in TBST buffer [10 $\mathrm{mM}$ Tris/ $\mathrm{HCl}$ (pH 7.4), $100 \mathrm{mM} \mathrm{NaCl}, 0.1 \%$ Tween 20] for $1 \mathrm{~h}$. Membranes were blocked with non-fat milk dissolved in TBSF buffer at room temperature for $2 \mathrm{~h}$, followed by incubation with primary antibodies (anti-Flag, PROTEINTECH, Cat No. 20543-1-AP at 1:5000 dilution; anti-tubulin rabbit polyclonal antibody, BBI, Cat No. D110015 at 1:5000 dilution). Membranes were washed with TBSF and incubated with an HRP-conjugated goat anti-rabbit IgG (BBI, Cat No. D110058 at 1:5000 dilution). The blots were washed with TBSF buffer again, and the bands were visualized using an enhanced chemiluminescene method.

\section{GUS activity assay}

Ganoderma lucidum mycelia scraped from CYM plate were stained with GUS detection buffer [0.1 M sodium phosphate ( $\mathrm{pH} 7.0$ ), $0.5 \mathrm{mg} / \mathrm{mL}$ X-Gluc, $0.05 \mathrm{mM} \mathrm{K}_{3}$ $\left(\mathrm{Fe}[\mathrm{CN}]_{6}\right), 0.05 \mathrm{mM} \mathrm{K}_{4}\left(\mathrm{Fe}[\mathrm{CN}]_{6}\right)$, and $0.5 \%$ Triton X-100] on a glass slide for 20 and $40 \mathrm{~min}$, respectively. After washing with $\mathrm{PB}$ buffer $(10 \mathrm{mM}$ sodium phosphate, $\mathrm{pH}$ 7.0 ), the mycelia were observed under a Nikon Coolpix 900 camera.

\section{Statistical analysis}

Data were generated in three independent sample measurements, and all data are presented as the mean \pm standard deviation. The results were considered significant for $p$ values $<0.05$ in a two-tailed analysis.

\section{Supplementary Information}

The online version contains supplementary material available at https://doi. org/10.1186/s12934-021-01654-8.
Additional file 1. Data S1. The synthesized gene sequence. Fig. S1. Selection of phosphinothrin-resistant transformants on a selective CYM plate. (A) Transformants on a selective CYM plate. 1, 2, 3, 4: Strains transformed with pJW-EXP-in (M)-opbar-flag. (B) Identificaton of G. lucidum transformants by PCR. Fig. S2. Selection of phosphinothrin-resistant transformants on a selective CYM plate. (A) Transformants on a selective CYM plate. 1, 2, 3, 4: Strains transformed with pJW-EXP-opbar-flag-in. (B) Identificaton of G. lucidum transformants by PCR. Fig. S3. Identificaton of G. lucidum transformants with plasmid pJW-EXP-opgus (A) and pJW-EXPin-opgus (B) by PCR. Table S1. Oligonucleotides used in this study.

\section{Acknowledgements}

Not applicable.

\section{Authors' contributions}

JWX designed the study. HY, BS and NL conducted the experiments. JWX, HY and NL analyzed the data. HY and JWX wrote the manuscript. All authors read and approved the final manuscript.

\section{Funding}

The National Natural Science Foundation of China (No. 81860668) and the Yunnan Applied Basic Research Project (No. 2018FB065) supported this study. J.-W. Xu also thanks to the Yunnan Ten Thousand Talents Plan-Young \& Elite Talents Project.

\section{Declarations}

Ethics approval and consent to participate

Not applicable.

\section{Consent for publication}

Not applicable.

\section{Competing interests}

The authors declare that they have no competing interests.

\section{Author details}

${ }^{1}$ Faculty of Life Science and Technology, Kunming University of Science and Technology, Kunming 650500, China. ${ }^{2}$ Faculty of Science, Kunming University of Science and Technology, Kunming 650500, China.

Received: 11 May 2021 Accepted: 12 August 2021

Published online: 21 August 2021

\section{References}

1. Hsu KD, Cheng KC. From nutraceutical to clinical trial: frontiers in Ganoderma development. Appl Microbiol Biotechnol. 2018;102:9037-51.

2. Russell R, Paterson M. Ganoderma-a therapeutic fungal biofactory. Phytochemistry. 2006;67:1985-2001.

3. Boh B. Ganoderma lucidum: a potential for biotechnological production of anti-cancer and immunomodulatory drugs. Recent Patient Anti-Cancer Drug Discov. 2013;8:255-87.

4. Li HJ, Zhang DH, Yue TH, Jiang LX, Yu X, Zhao P, Li T, Xu JW. Improved polysaccharide production in a submerged culture of Ganoderma lucidum by the heterologous expression of Vitreoscilla hemoglobin gene. J Biotechnol. 2016;217:132-7.

5. Qin H, Xu JW, Xiao JH, Tang YJ, Xiao H, Zhong JJ. Cell factories of higher fungi for useful metabolite production. Adv Biochem Eng Biotechnol. 2016;155:199-235.

6. Fei Y, Li N, Zhang DH, Xu JW. Increased production of ganoderic acids by overexpression of homologous farnesyl diphosphate synthase and kinetic modeling of ganoderic acid production in Ganoderma lucidum. Microb Cell Fact. 2019:18:115.

7. Feng J, Feng N, Tang Q, Liu Y, Tang C, Zhou S, Wang J, Tan Y, Zhang J, Lin CC. Development and optimization of the triterpenoid and sterol production process with Lingzhi or Reishi medicinal mushroom, Ganoderma 
lucidum strain G0017 (agaricomycetes), in liquid submerged fermentation at large scale. Int J Med Mushrooms. 2021;23:43-53.

8. Chen S, Xu J, Liu C, Zhu Y, Nelson DR, Zhou S, Li C, Wang L, Guo X, Sun Y, Luo H, Li Y, Song J, Henrissat B, Levasseur A, Qian J, Li J, Luo X, Shi L, He L, Xiang L, Xu X, Niu Y, Li Q, Han MV, Yan H, Zhang J, Chen H, Lv A, Wang Z, Liu M, Schwartz DC, Sun C. Genome sequence of the model medicinal mushroom Ganoderma lucidum. Nat Commun. 2012;3:913.

9. Yu GJ, Wang M, Huang J, Yin YL, Chen YJ, Jiang S, Jin YX, Lan XQ, Wong BHC, Liang Y, Sun H. Deep insight into the Ganoderma lucidum by comprehensive analysis of its transcriptome. PLoS ONE. 2012;7:e44031.

10. Yu GJ, Yin YL, Yu WH, Liu W, Jin YX, Shrestha A, Yang Q, Ye XD, Sun H. Proteome exploration to provide a resource for the investigation of Ganoderma lucidum. PLoS ONE. 2015;10:e0119439.

11. Shao J, Wang L, Liu X, Yang M, Chen H, Wu B, Liu C. Identification and characterization of circular RNAs in Ganoderma lucidum. Sci Rep. 2019:9:16522

12. Xu JW, Xu YN, Zhong JJ. Enhancement of ganoderic acid accumulation by overexpression of an $\mathrm{N}$-terminally truncated 3-hydroxy-3-methylglutaryl coenzyme A reductase gene in the basidiomycete Ganoderma lucidum. Appl Environ Microbiol. 2012;78:7968-76.

13. Yu X, Ji SL, He YL, Ren MF, Xu JW. Development of an expression plasmid and its use in genetic manipulation of Lingzhi or Reishiem medicinal mushroom Ganoderma lucidum (higher basidiomycetes). Int J Med Mushrooms. 2014;16:161-8.

14. Xu JW, Zhong JJ. Genetic engineering of Ganoderma lucidum for the efficient production of ganoderic acids. Bioengineered. 2015;6:357-60.

15. Qin H, Xiao H, Zou G, Zhou Z, Zhong JJ. CRISPR-Cas9 assisted gene disruption in the higher fungus Ganoderma species. Process Biochem. 2017;56:57-61.

16. Liu K, Sun B, You H, Tu JL, Yu X, Zhao P, Xu JW. Dual sgRNA-directed gene deletion in basidiomycete Ganoderma lucidum using the CRISPR/Cas9 system. Microb Biotechnol. 2020;13:386-96.

17. Schuren FHJ, Wessels JGH. Expression of heterologous genes in Schizophyllum commune is often hampered by the formation of truncated transcripts. Curr Genet. 1998;33:151-6.

18. Ford KL, Baumgartner K, Henricot B, Bailey AM, Foster GD. A native promoter and inclusion of an intron is necessary for efficient expression of GFP or mRFP in Armillaria mellea. Sci Rep. 2016;6:29226.

19. Scholtmeijer K, Wosten HAB, Springer J, Wessels JGH. Effect of introns and AT-rich sequences on expression of the bacterial hygromycin B resistance gene in the basidiomycete Schizophyllum commune. Appl Environ Microbiol. 2001;67:481-3.

20. Burns C, Gregory KE, Kirby M, Cheung MK, Riquelme M, Elliott TJ, Challen MP, Bailey A, Foster GD. Efficient GFP expression in the mushrooms
Agaricus bisporus and Coprinus cinereus requires introns. Fungal Genet Biol. 2005;42:191-9.

21. Kilaru S, Collins CM, Hartley AJ, Bailey AM, Foster GD. Establishing molecular tools for genetic manipulation of the pleuromutilin-producing fungus Clitopilus passeckerianus. Appl Environ Microbiol. 2009;75:7196-204.

22. Lugones LG, Scholtmeijer K, Klootwijk R, Wessels JGH. Introns are necessary for mRNA accumulation in Schizophyllum commune. Mol Microbiol. 1999;32:681-9

23. Ma B, Mayfield MB, Gold MH. The green fluorescent protein gene functions as a reporter of gene expression in Phanerochaete chrysosporium. Appl Environ Microbiol. 2001;67:948-55.

24. XU J, Gong ZZ. Intron requirement for AFP gene expression in Trichoderma viride. Microbiology. 2003;149:3093-7.

25. Laxa M. Intron-mediated enhancement: a tool for heterologous gene expression in plants? Front Plant Sci. 2017;7:1977.

26. Bilyk B, Horbal L, Luzhetskyy A. Chromosomal position effect influences the heterologous expression of genes and biosynthetic gene clusters in Streptomyces albus J1074. Microb Cell Fact. 2017;16:5.

27. Noe V, MacKenzie S, Ciudad CJ. An intron is required for dihydrofolate reductase protein stability. J Biol Chem. 2003;278:38292-300.

28. Shaul O. How introns enhance gene expression. Int J Biochem Cell Biol. 2017:91:145-55.

29. Emami S, Arumainayagam D, Korf I, Rose AB. The effects of a stimulating intron on the expression of heterologous genes in Arabidopsis thaliana. Plant Biotechnol J. 2013;11:555-63.

30. Sun B, You H, Xu JW. Enhancement of ganoderic acid production by promoting sporulation in a liquid static culture of Ganoderma species. J Biotechnol. 2021;328:72-7.

31. Xu JW, Xu YN, Zhong JJ. Production of individual ganoderic acids and expression of biosynthetic genes in liquid static and shaking cultures of Ganoderma lucidum. Appl Microbiol Biotechnol. 2010:85:941-8.

32. Xu JW, Yue TH, Yu X, Zhao P, Li T, Li N. Enhanced production of individual ganoderic acids by integrating Vitreoscilla haemoglobin expression and calcium ion induction in liquid static cultures of Ganoderma lingzhi. Microb Biotechnol. 2019;12:1180-7.

33. Zhang DH, Jiang LX, Li N, Yu XY, Zhao P, Li T, Xu JW. Overexpression of the squalene epoxidase gene alone and in combination with the 3-hydroxy3-methylglutaryl coenzyme A gene increases ganoderic acid production in Ganoderma lingzhi. J Agric Food Chem. 2017;65:4683-90.

\section{Publisher's Note}

Springer Nature remains neutral with regard to jurisdictional claims in published maps and institutional affiliations.
Ready to submit your research? Choose BMC and benefit from:

- fast, convenient online submission

- thorough peer review by experienced researchers in your field

- rapid publication on acceptance

- support for research data, including large and complex data types

- gold Open Access which fosters wider collaboration and increased citations

- maximum visibility for your research: over $100 \mathrm{M}$ website views per year

At BMC, research is always in progress.

Learn more biomedcentral.com/submissions 